\title{
WEAR BEHAVIOR OF STEPPED AUSTEMPERED DUCTILE IRON BALLS IN GRINDING IRON ORE
}

\author{
Jayaraj B.Siddan ${ }^{1}$ \\ ${ }^{1}$ Assistant Prof, Mechanical Engg. Dept, Bheemanna Khandre Institute of Technology, Bhalki 585328, Karnataka state, \\ India
}

\begin{abstract}
In the present study, an attempt has been made to evaluate the suitability of austempered ductile iron as grinding media material for grinding the iron ore in a ball mill. They are austenitised at $920^{\circ} \mathrm{C}$ for 60 minutes and given stepped austempering heat treatment: $400{ }^{\circ} \mathrm{C}$ for 15, 30, 45, and 60 minutes followed by $300{ }^{\circ} \mathrm{C}$ for 120 minutes for each case. Grinding wear behaviour of these materials are assessed for wear loss in wet condition. The grinding operation are carried out for 60 minutes at $60 \%$ pulp density under closed mill conditions. The $\mathrm{pH}$ of mineral slurry is varied from 7 to $10.5 \mathrm{pH}$ to assess the influence of $\mathrm{pH}$ on grinding wear behavior of ball material. It is found that wear rate of grinding media material increases proportionally with decrease in $p H$. These wear rate values are compared with En-31 forged steel under similar conditions. It is found that wear resistance of stepped austempered ductile iron is superior compared to En-31 forged steel balls for wet condition.
\end{abstract}

Keywords: Austemper ductile iron, wear, grinding, ball mill.

\section{INTRODUCTION}

The term austempered ductile iron (ADI) describes a range of nodular (S.G) Iron (Ductile irons) which have been subjected to an isothermal (austempering) heat treatment to produce an essentially bainitic structure in the material. These materials possess high strength with high ductility, wear resistance and fatigue strength. The remarkable combination of properties attainable has caused this material to emerge as a new class of ductile iron. [1] The matrix of ADI is composed of bainitic ferrite together with retained austenite. The morphology and properties of these micro constituents control the mechanical properties. By varying the heat treatment parameters like austenising temperature, austempering temperature and time, stepped austempering temperature and time and alloy composition, the morphology of ADI could be altered. [2]

Wear is one of the most commonly encountered industrial problems. Wear is defined as progressive losses of material from a surface as a result of relative motion between the surface and another. Wear contributes to the diminished usefulness of an item through changes in dimension appearance or structural integrity. [3]

Wear of grinding media material possesses significant problem leading to substantial increases in the production cost. It is not only because of replacement of costly material but also due to the loss of production caused by premature wear or breakage of balls. In the wet grinding of ores, the cost of grinding media wear often approaches and at times even exceeds the electrical power cost. An estimated over 5, 00,000 tones of iron and steel are consumed as grinding media every year around the world. Grinding is an essential and unavoidable procedure preceding many concentration operations.

Ball wear in grinding mills is contributed by abrasion, impact, corrosion and erosion. Identification of the roles that each of these components play in bringing about ball wear would provide necessary information leading to the reduction of media wear and thereby the overall processing cost. [4]

In the present work the S.G. balls are austenitised at $920^{\circ} \mathrm{C}$ for 60 minutes and given stepped austempering heat treatment: $400{ }^{\circ} \mathrm{C}$ for $15,30,45,60$ minutes fallowed by $300{ }^{\circ} \mathrm{C}$ for 120 minutes for each case. Wear studies were carried out for these samples in ball mill (closed condition, wet type grinding, $60 \%$ pulp density) at different $\mathrm{pH}$ values. An attempt is made to compare the grinding wear properties. with forged En-31 steel balls.

\section{LITERATURE REVIEW}

The ductile cast iron was first announced to the foundry industry as a new engineering material in the year1948. This revolutionary material, discovered independently by the British cast Iron Research Association (BCIRA) and International Nickel Company (INCO) by three scientists N.B.Billing Keith D. Millies and A.P Gogriebin is also referred to as nodular or spheroidal, graphite cast Iron [5]

Interest in austempered ductile irons has increased dramatically in the past few years as more and more successful applications are being reported. Austempering of 
SG iron is known as developing a group of high strength high toughness and wear resistance variety of SG iron called austempered ductile iron. The first large-scale application of ADI was general motors ring gear and pinion announced in 1976. However, an extensive development program was undertaken in the early 1950 to find the best alternative material to a cast steel track shoes. Today there are many applications to ADI.. [6]

ADI also offers unique advantages such as:i) decrease in weight $(\geq 10 \%)$ of the manufactured part,ii) superior casting characteristics which not only enhances the dimensional precision, reductions of the cost of machineries, but also reduce the cost of melting process,iii) higher wear resistance due to the presence of graphite and an unique combinations of micro constituents, and iv) superior fatigue resistance commonly attributed to the retained austenite, which transforms to martensite during service. Bainite material in ductile irons can be obtained in two ways i) In as cast form where bainite transformations is achieved by judicious alloying. ii) By subjecting normal ductile iron casting to specialized heat treatment known as austempering. [7]

\subsection{Austempering Heat Treatment}

The term austempering is used to describe an isothermal form of heat treatment, which contains following steps: i) heating normal ductile iron castings to temperature above the upper critical temperature $\left(850--950^{\circ} \mathrm{C}\right)$ and soaking for duration varying from one hour to four hour depending on the section thickness and the amount of effective carbides. ii) quenching the above in a fluidized salt bath maintained at temperature in the range between martensitic start temperature (Ms) and pearlite formation temperature (i.e. between 235 to $4500 \mathrm{C}$ ), at a rate fast enough to avoid the transformation of austenite to pearlite. iii) holding in the salt bath long enough to form the desired mixture of various micro constituents of bainite. iv) the air-cooling and water quenching of the components from austempering temperature to room temperature, after holding it for known length of time. Schematic design of austempering heat treatment cycle of ADI is shown in below fig. 1

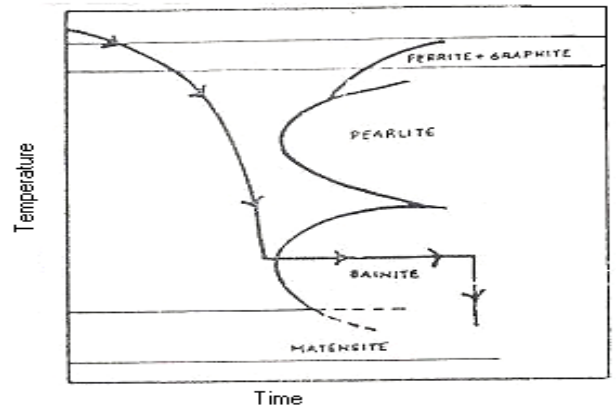

Fig.1: Schematic design of austempering heat treatment cycle of ADI

\subsection{Wear}

Wear is one of the three most commonly encountered industrial problems leading to the replacement of component and assemblies in engineering, other being fatigue and corrosion. Wear is rarely catastrophic but it reduces operating efficiency by increasing the poser losses, oil consumption, and rate of component replacement. Wear may define as the removal of material from solid surface as a result of mechanical action. It is a characteristic feature of the wear process that the amount of material removed is quite small.. In the case of grinding of different ore minerals factors that affect ball wear can be summarized under three headings. 1 The ore where hardness (abrasiveness), mineralogy, e.g. Presence of corrosive species and particle size are more important parameters.2 The mill - where composition, microstructure and mechanical properties of the balls and liner, quantity and size of balls, size of mill and mill speed are more important parameters. 3 The mill environment- such as the mill water chemistry and $\mathrm{pH}$, oxygen potential in the mill, percent solid and temperature. [8]

\subsection{Ball Mill}

The ball mills date back to 1876 and are characterized by the use of balls (made of iron, steel or tungsten carbide) as grinding medium. These mills are horizontal, rotating cylindrical or cylindroconical steel shells, usually working as continuous machines. The size reduction is accomplished by the impact of these balls as they fall back after being lifted to a certain height by the rotating shell. The length of the cylinder is normally equal to the diameter. The feed enters at one end and the product is discharged either through the opposite end or through the periphery. The ball mills may be operated dry or wet. The product may also be discharged by overflow through a hallow trunnion and the finer particles are carried away by the circulation fluid (air or water). The internal working faces of mills consist of renewable liners. The purpose of these liners is to withstand impact force, to protect the mill shell from wear and to reduce the slip between the shell, and grinding media. The commonly used liners are rubber liners and Ni hard liners.[9]

\subsection{Ball Wear}

The wide range of materials used to resist wear in comminuting processes. Wear processes in ball and rod mills have recently received increased attention in order to increase efficiency and conserve grinding media. The cost of grinding media wear approaches and often exceeds the electrical power cost. An estimated more than 300,000 tons of iron and steel are consumed annually by the U.S. mineral industry (Nasss, 1974; committee on comminution and energy consumption, 1981), with the present trend towards lower grade ores requiring finer grinding for liberation, the grinding media consumption per tone of concentrate recovered would be steadily increasing. The total wear of grinding media in ball 
mills consists of corrosion, abrasion and impact. Identification of the roles that each of these components play in ball wear would provide the information's leading the reduction of media wear and there by the overall processing cost..Dry grinding would give strictly abrasive wear. The wear rate during wet grinding has been observed as more than twice that in dry grinding and this difference has been attributed to corrosion effects. The dry grinding was considerably less efficient than wet grinding[10]

\section{EXPERIMENTAL WORK}

Experiments were carried out to assess the wear behavior of austempered ductile iron balls in grinding the Iron ore (supplied by KISCO. Mangalore) S.G. Iron of known composition is heat treated by austenitising at $920^{\circ} \mathrm{C}$ and stepped austempering at different temperature for different first austempering time and maintaining second austempering time constant.

\subsection{Heat treatment for ADI Preparation}

Austenitising was carried out in a Muffle silicon carbide electrical resistance furnace, with automatic temperature controller [shown in Fig.3.1 (a)], which ensures the temperature variation at the range of $\pm 50 \mathrm{C}$. Before austenitising all the balls were given copper coating to avoid decarburization. Austenitising treatment is carried out for the homogenized balls at $920^{\circ} \mathrm{C}$ for one hour. At the end of austenitisation the balls were dropped into the first salt bath for I step austempering maintained at the preset temperature $400^{\circ} \mathrm{C}$ for the time duration of $15,30,45,60$ minutes and balls removed from first salt bath and quenched in second salt bath for II step austempering maintained at the preset temperature $300^{\circ} \mathrm{C}$ for 120 minute. The salt bath used for austempering treatment was a mixture of sodium nitrate and potassium nitrate (55:45) [Shown in Fig.2]. The temperatures and time conditions selected for the austempering treatment of balls were presented in Table 1

Table 1: Two Step Austempering condition

\begin{tabular}{|c|c|c|c|c|c|c|}
\hline \multirow{2}{*}{ Type } & \multicolumn{2}{|c|}{ Austenitising } & \multicolumn{2}{c|}{ First step austempering } & \multicolumn{2}{c|}{ Second step austempering } \\
\cline { 2 - 7 } & $\begin{array}{l}\text { Temp.( } \\
\left.{ }^{\circ} \mathbf{C}\right)\end{array}$ & $\begin{array}{l}\text { Time } \\
(\text { min) }\end{array}$ & $\begin{array}{l}\text { Austempering } \\
\text { Temp. }\left({ }^{\circ} \mathbf{C}\right)\end{array}$ & $\begin{array}{l}\text { Austempering } \\
\text { time (min.) }\end{array}$ & $\begin{array}{l}\text { Austempering } \\
\text { Temp. }\left({ }^{\circ} \text { C }\right)\end{array}$ & $\begin{array}{l}\text { Austempering } \\
\text { time (min.) }\end{array}$ \\
\hline A & 920 & 60 & 400 & 15 & 300 & 120 \\
\hline B & 920 & 60 & 400 & 30 & 300 & 120 \\
\hline C & 920 & 60 & 400 & 45 & 300 & 120 \\
\hline D & 920 & 60 & 400 & 60 & 300 & 120 \\
\hline
\end{tabular}

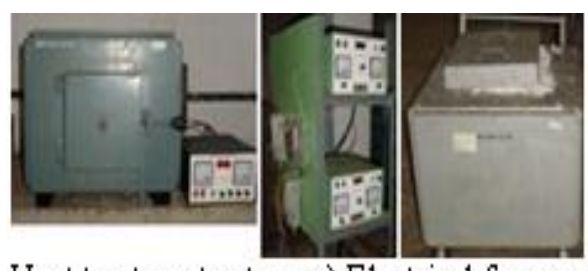

Heat treatment set up: a) Electrical fumace with temperature controller for Austeritising b) Salt baths for austempering treatment

Fig.2 Heat treatment set up

\subsection{Experimental Set-Up}

The ball mill set-up used in the present experimental study for grinding work is shown in the Fig.3. The ball mill is basically a cylindrical shell having a length of $29.46 \mathrm{~cm}$ and diameter of $20.32 \mathrm{~cm}$. The mill is lined with neoprene rubber. The ball mill is closed at one end and a detachable lid is provided at the other end. This lid can be fixed to the mill with the help of bolts and nuts. At the center the lid is having a hole of $3 \mathrm{~mm}$ diameter through which air or oxygen could be sent during wet grinding to study the influence of different kinds of aeration on ball wear. Another hole having the diameter of
$3 \mathrm{~mm}$ is provided on the face of the other end of the mill, which serves as an outlet for either air or oxygen during wet grinding. The ball mill runs with the speed of $86 \mathrm{rpm}$.

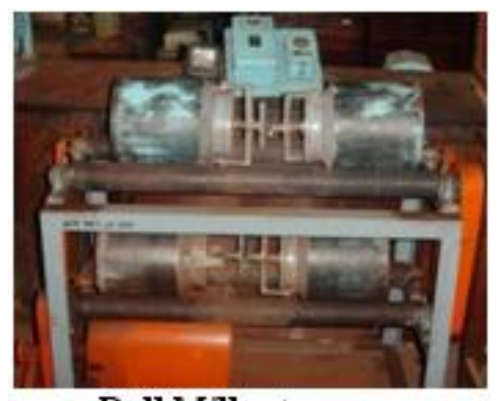

Ball Mill set-up

Fig.3: Ball mill set -up

\subsection{Grinding Media}

A set of 200 balls of dia. $2.5 \mathrm{~cm}$ ( 25 marked balls) were used to carry out the grinding experiments. The results of the ADI balls austempered at different conditions and EN-31 steel forged balls are compared under different experimental conditions. 


\subsection{Assessment of Grinding Media Wear}

Grinding media wear tests were carried out in the laboratory sealed rubber lined ball mill. The iron ore sample of size 10+30 mesh was used for the experiments. Sets of 200 balls were used as grinding media, which included 25 marked balls. The ball mill was rotated at $86 \mathrm{rpm}$. The total mill charge consisted of 1500 gms of iron ore sample and $1000 \mathrm{ml}$ water (in the case of wet grinding) which amounts to $60 \%$ pulp density, held at different choice of $\mathrm{pH}$ i.e. 7, 910.5 along with the grinding media balls. The $\mathrm{pH}$ value was selected by adding lime to the distilled water. After each grinding experiment the 25 marked balls were handpicked, rinsed well with distilled water and then tumbled in the plastic tray with acetone. The balls were then dried with hot air and kept in hot air oven for one hour and maintained temperature of $100 \mathrm{oC}$. Later they were kept in the airtight desiccators to cool for at least three to four hours. After cooling the marked balls were accurately weighed in the electronic balance and difference in weight (initial weight before grinding and final weight after grinding) in terms of gms per ball was calculated. The wear rate was calculated using the formula

\section{Wear rate, $\left(\mathrm{cm}^{3}\right)=\frac{\text { Wear }(\text { gms/ball) }}{\mathrm{T}} \mathrm{X}$ Total no. Of rev. Density of ball material}

The slurry obtained was filtered using pressurized filtering equipment and dried in an oven. The filtered water sample is collected for the $\mathrm{pH}$ measurement. A representative sample of 100 grams was taken from the powdered cake after coning and quartering and subjected to sieve analysis.

Table.2 Experiment Conditions

\begin{tabular}{|l|l|}
\hline Size of ore sample & $\begin{array}{l}-10 \quad+30 \text { mesh (as per } \\
\text { ASTM) }\end{array}$ \\
\hline Total no. Of ball used & $\begin{array}{l}200 \quad(25 \text { marked ball), of } \\
\text { size } 25 \mathrm{~mm} \Phi\end{array}$ \\
\hline Type of Grinding & $\begin{array}{l}\text { Wet grinding (close mill } \\
\text { condition) }\end{array}$ \\
\hline Pulp Density & $60 \%$ \\
\hline Grinding Time & $60 \mathrm{~min}$. \\
\hline $\begin{array}{l}\text { Total no. of revolution of } \\
\text { ball mill }\end{array}$ & 5160 \\
\hline $\begin{array}{l}\text { Density of ball materials: } \\
\text { ADI }\end{array}$ & $7.2 \mathrm{~g} \mathrm{/cm3}$ \\
\hline (forged) En-31 Steel & $7.6 \mathrm{~g} / \mathrm{cm} 3$ \\
\hline
\end{tabular}

\section{RESULTS AND DISCUSSION}

S.G. Iron balls containing $1.37 \% \mathrm{Ni}$ and $0.28 \%$ Mo were austempered for 15 minutes, 30, 45, and 60 minutes at $4000 \mathrm{C}$ fallowed by $3000 \mathrm{C}$ for 120 minutes (two step austempering) separately to produce different microstructure. These balls were used as grinding media in iron ore grinding. These wear behavior of the ADI material is compared with En-31 steel forged balls.

Table 3: Chemical composition of iron ore and S.G

\begin{tabular}{|c|c|c|c|c|c|c|}
\hline Elements & $\mathrm{Fe}$ & $\mathrm{Si}$ & $\begin{array}{l}\text { Alumi } \\
\text { na }\end{array}$ & $\begin{array}{l}\text { Sulph } \\
\text { ur }\end{array}$ & $\begin{array}{l}\text { Phosphor } \\
\text { ous }\end{array}$ & $\begin{array}{l}\text { Mangan } \\
\text { ese }\end{array}$ \\
\hline $\begin{array}{l}\text { Composit } \\
\text { ion } \\
(\mathrm{Wt} \%)\end{array}$ & $\begin{array}{l}65 . \\
5\end{array}$ & $\begin{array}{l}1 . \\
6- \\
1 . \\
8\end{array}$ & 1.8 & 0.007 & 0.07 & 0.05 \\
\hline
\end{tabular}

Table 4: Chemical composition of S.G. iron

\begin{tabular}{|l|l|l|l|l|l|l|l|}
\hline Elements & $\mathrm{C}$ & $\mathrm{Si}$ & $\mathrm{P}$ & $\mathrm{Mn}$ & $\mathrm{Mo}$ & $\mathrm{Ni}$ & $\mathrm{Mg}$ \\
\hline Compositio & 3. & 2.6 & 0.01 & 0.3 & 0.3 & 1.3 & 0.00 \\
$\mathrm{n}$ & 5 & 2 & 8 & 3 & 0 & 7 & 4 \\
$(\mathrm{Wt} \%)$ & & & & & & & \\
\hline
\end{tabular}

Table .5: Wear behavior

\begin{tabular}{|c|c|c|c|}
\hline \multirow{2}{*}{$\begin{array}{l}\text { Austempering } \\
\text { type }\end{array}$} & \multicolumn{2}{|c|}{ pH values } & \multirow{2}{*}{$\begin{array}{l}\text { Wear rate cm } \\
3 / \text { rev. } \\
(\times 10-8)\end{array}$} \\
\hline & $\begin{array}{l}\text { Initial } \\
\mathrm{pH} 1\end{array}$ & $\begin{array}{l}\text { Final } \\
\text { pH } 2\end{array}$ & \\
\hline \multirow[b]{3}{*}{ A } & 7.00 & 6.75 & 658.64 \\
\hline & 9.00 & 7.45 & 180.07 \\
\hline & 10.5 & 7.60 & 122.20 \\
\hline \multirow[b]{3}{*}{ B } & 7.00 & 6.80 & 1105.5 \\
\hline & 9.00 & 7.47 & 208.01 \\
\hline & 10.5 & 7.40 & 118.00 \\
\hline \multirow[b]{3}{*}{$\mathrm{C}$} & 7.00 & 6.70 & 1045.86 \\
\hline & 9.00 & 7.50 & 302.21 \\
\hline & 10.5 & 8.00 & 148.68 \\
\hline \multirow[b]{3}{*}{ D } & 7.00 & 6.69 & 819.55 \\
\hline & 9.00 & 7.30 & 187.01 \\
\hline & 10.5 & 7.10 & 95.93 \\
\hline \multirow[b]{4}{*}{$\begin{array}{l}\text { EN } \quad-31 \\
\text { STEEL } \\
\text { (FORGED) }\end{array}$} & 7.00 & 6.65 & 1178.85 \\
\hline & 9.00 & 6.80 & 546.97 \\
\hline & 10.5 & 6.95 & 319.51 \\
\hline & & & \\
\hline
\end{tabular}




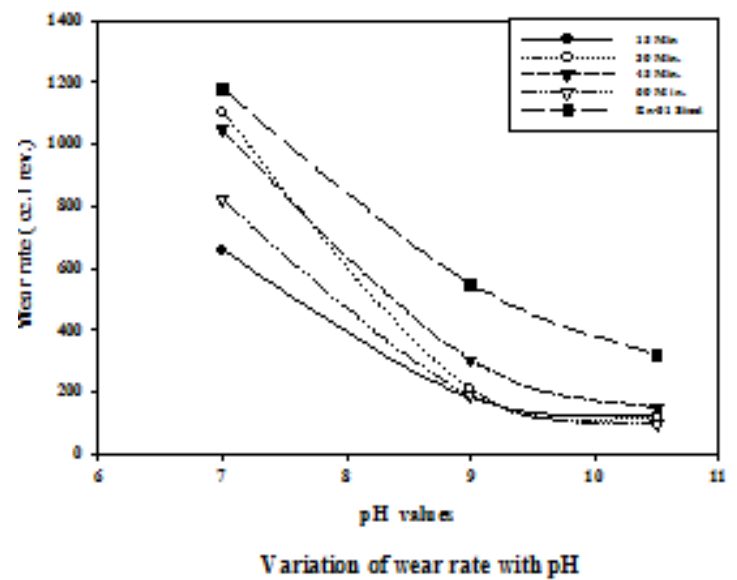

Fig.4 variation of wear rate with $\mathrm{Ph}$

\subsection{Grinding Wear Behavior of ADI Materials}

It is observed in the present investigation that grinding wear resistance of ADI is superior to that of En-31 steel (forged) in wet, close mill condition of grinding. This suggests that ADI is definitely superior material in grinding iron ore. Further it should be noted that the advantage seems to be uniform in all $\mathrm{pH}$ range. Wear behavior of ADI is sensitive to the microstructure at lower $\mathrm{pH}$ level .The superior wear behavior exhibited by ADI material is because of its special micro structural feature. The ADI consists of graphite nodules embedded in bainitic matrix. Bainite in the case of ADI is different from that in steel material. In the cases ADI they are the combination of ferrite lath and retained austenite distributed in between the ferrite path. Retained austenite with low carbon content may undergo stress-induced transformation and get converted to martensite. This process offers resistance to crack propagation and hence improve the wear behavior.

Among ADI those austempered at $400{ }^{0} \mathrm{C}$ for 15 minutes fallowed by $300{ }^{\circ} \mathrm{C}$ for 120 minutes resister minimum wear rate. This is due to ADI material posses refined bainitic microstructure and high hardness.

ADI austempered in B type (i.e. austemperd at $400{ }^{\circ} \mathrm{C}$ for 30 minutes fallowed by $300{ }^{0} \mathrm{C}$ for 120 minutes shows higher wear rate than other type of heat treatment. This is due to reduction in fineness of microstructure

The material austempered ion D type contains higher amount of retain austenite with lower carbon content. These retained austenite are expected to the unstable under the influence of high stress which would arrange at the surface of the ball due to impact during grinding operation. In such cases retained austenite will converted into the martensite. This could be contributing factor for these material could resister higher wear resistance.

\subsection{Effect of $\mathrm{pH}$ on Wear Behavior}

Wet grinding in ball mill involves abrasive and corrosive wear processes. Hoey et al noted in his investigation that as the $\mathrm{pH}$ of ore slurry increased by addition of Sodium hydroxide the wear losses decreased. The corrosion resistance of steel of any composition is known to increase as $\mathrm{pH}$ increases there by decreasing wear resistance at high $\mathrm{pH}$ range. At lower $\mathrm{pH}$ nearer neutrality a hydrated oxide (Fe O $\mathrm{OH}$ ) is the corrosion product which is only loosely attached to the surface and is therefore easily removed by abrasion.

In the present investigation, it is found that wear loss is more at lower $\mathrm{pH}$ (near neutrality) and wear loss is less at higher $\mathrm{pH}$. Wear rate decreases as increase in $\mathrm{pH}$ value. At higher $\mathrm{pH}$ range it is very well known fact that the film is stable that become a weathering protective passive which protects the surface of material during impact at the toe zone and shear force acting parallel to the surface of the mill. In absence of such a passive layer at lower $\mathrm{pH}$ range. Surface is exposed to all abrasive force and corrosive atmosphere.

From table 5 it is observed that the $\mathrm{pH}$ value of slurry decreases from initial value after the grinding process. This is because of liberation of gang's materials, which are acid in nature. So the solution becomes acidic.

\section{CONCLUSIONS}

The fallowing conclusions were drawn from the present study.

1. Wear rate was found to be decreased with increasing $\mathrm{pH}$ of the ore slurry. Both the grinding media balls exhibited this behaviour.

2. The grinding wear resistance of austempered ductile iron balls was found to be better than that of En-31 forged steel ball

3. The wear behavior of ADI balls at lower $\mathrm{pH}$ is sensitive to the microstructure and at higher $\mathrm{pH}$ insensitive to the microstructure.

4. The wear behavior of ADI in grinding of iron ore is not only dependent on the hardness but also on the microstructure, phase constituents of the ADI material

\section{REFERENCES}

[1] H. L. Morgan, “ Introduction to Foundry Production and Control of Austempered Ductile Irons", IBF Conference paper, The British Foundry Man, Feb/March 1987, 98-108

[2] R.B.Gunlach\& J.F Janowak"A Review of Austempered Ductile Iron Metallurgy", Metal Progress -19, July 1985, 1-12

[3] Ernes Rabinowiez, "Friction and Wear of Materials", John Wiely \& Sons Inc. New Yark, 1965, 109-119

[4] C.S.Gundwar, K.A..Natrajan, Nayak \& Satyanarayana, "Studies on Ball Wear in Grinding of Kudremukh 
Hematite -Magnetite ore", Mineral Engineering, Vol.-3 No.-12, 1990, 207-220

[5] Richard W. Heine, Carl.R.Loper, Jr.and Philip C.Rosenthal. "Principle of Metal Casting'"Mc. GrawHill Book Company New Yark, II edition, 1967, 614641

[6] Lyle R. Jenkins, R.D.Forrest, and others "Properties and Selection: Irons, Steels and High Performance Alloys" ASM Hand Book vol-01, $10^{\text {th }}$ Edition, 2001 33-55

[7] Krishna D, Murthy V.S.R.and Sheshan "Studies on Thin Sectioned Bainitic Ductile Iron" British Foundry Men -80, Part-6, 1985.

[8] J.J.Moore, Perez, Gangopadhyay \& J.J.Eggert", Factors Affecting Wear in Tumbling Mill: Influence of Composition \& Microstructure", Int. J. Miner. Process, Vol-22, 1988 313-343

[9] P. Prasad Rao "Austempered Ductile Iron: Microstructure and Properties", Workshop, I.I.F Mangalore Chapter, Dec. 1998, 42-62

[10] M. Nili Ahmadabadi, H.M. Ghasemi, M. Osia, "Effect of Successive Austempering on the Triboligical Behaviour of Ductile Cast Iron”, Wear, 231, 1999, 293 320

[11] H. B. Shashidhara, "Studies on Wear Behaviour of Austempered Ductile Iron Balls in Grinding Gold ore", M.Tech. Thesis, N I T K Suratkhal

[12] Jayaraj B Siddan "Laboratory studies on the wear behaviour of stepped austempered ductile iron balls in grinding iron ore" M.Tech. Thesi NITK Surtkhal. August 2014

\section{BIOGRAPHIES}

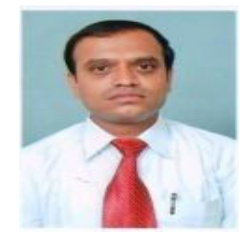

Jayaraj .B. Siddan, presently working as Assistant Prof. in the Department of Mechanical Engg., Bheemanna Khandre institute of technology Bhalki ( karnatataka state). He was completed M.Tech.( Material engineering) from National Institute of Technology Surtkhal.. Project done under guidance of Dr. Rajendra Udupa and Dr. K L Bhatt. Has excellent academic and teaching records, with 12 Year teaching experience and 2 year industrial experience. 